\title{
An Insect Toxin from Spores of Bacillus thuringiensis and Bacillus cereus
}

\author{
By H. J. SOMERVILLE AND HAZEL V. POCKETT \\ Shell Research Ltd, Woodstock Laboratory, Sittingbourne Research Centre, Sittingbourne \\ $M E 98 A G$, Kent
}

(Received I I October 1974; revised 20 November 1974)

SUMMARY

Spores of Bacillus thuringiensis contain a toxin active against lepidopterous larvae. This toxin can be solubilized by extraction with reagents which dissolve the protein crystal of $B$. thuringiensis. It is inactivated by crystal-specific antiserum. Spores of Bacillus cereus contain a similar toxin although the specific activity is much lower than the spores of $B$. thuringiensis. The $B$. cereus toxin contains a single major polypeptide component. Toxic activity can be solubilized from spores of both species by incubation with gut juices from Pieris brassicae.

\section{INTRODUCTION}

Bacillus thuringiensis is the only micro-organism that has been successfully developed as a microbial insecticide. The commercial exploitation of this organism stems from its toxicity to lepidopterous insects, and from its lack of toxicity to man. It is without known harmful effect to species outside Lepidoptera. The toxicity has generally been associated with the crystalline inclusion which is formed concomitant with sporulation, and insecticidal formulations of $B$. thuringiensis are based on mixtures of crystals and spores derived from culture broths.

Somerville (I97I) showed that, during its formation, the crystal is closely associated with a spore membrane - the exosporium. It was suggested that the exosporium forms a template for crystal assembly and that the crystal may be synthesized on this membrane. The crystals, which are largely, if not entirely, made up of polypeptides (Somerville, Delafield \& Rittenberg, 1968), have similar biochemical and immunological properties to those of a substantial fraction of spore protein (Delafield, Somerville \& Rittenberg, 1968). The latter material appears to be a unique sporulation product and has been tentatively located in the spore-coat. Similar material was found in spores of some other Bacillus species (Somerville, Delafield \& Rittenberg, 1970).

The present investigation was undertaken to establish whether the spore protein was toxic to Lepidoptera and to investigate its nature and relationship to the crystal toxin.

\section{METHODS}

Micro-organisms. The strains used were as follows and, except where indicated, were obtained as described previously (Somerville, 197I): Bacillus thuringiensis serotype-3 (S-3); $B$. thuringiensis S-9; two acrystalliferous ( $c r$ ) mutants of $B$. thuringiensis S-9, strains $\mathrm{HB}$ I and HB2, isolated after treatment of the wild type with $N$-methyl- $N^{\prime}$-nitro- $N$-nitrosoguanidine (Somerville et al. I968); B. cereus $64 \mathrm{a} ;$ B. megaterium NCIB8508; B. cereus T. Spores of 
Clostridium bifermentans were a gift from Dr W. M. Waites, and an $0 \cdot \mathrm{I} \mathrm{N}-\mathrm{NaOH}$ extract of spores of C. sporogenes was a gift from Dr G. W. Gould. All Bacillus strains were maintained on nutrient agar slopes.

The $B$. cereus 64 a culture used in the present work has previously been referred to as $B$. megaterium (Somerville et al. I970). Dr J. N. Claus identified the culture as B. cereus, and we confirmed his identification on the original culture, obtained from the Department of Bacteriology, University of California, Los Angeles, U.S.A.

Preparation of spores and crystals. Culture conditions and the methods used in the separation of crystals and spores were as described by Delafield et al. (1968). In preparations from $B$. thuringiensis, the purity of crystal and spore preparations was in each case better than $99.9 \%$ relative to the other. Crystals were stored as suspensions in distilled water at $4{ }^{\circ} \mathrm{C}$; spores were lyophilized and stored in a desiccator at room temperature.

Radioactive spores were prepared in the same way from plates of nutrient agar to which $\left[{ }^{14} \mathrm{C}\right]$ algal hydrolysate (Radiochemical Centre, Amersham, Buckinghamshire) was added.

Extraction of spores and dissolution of crystals. Three reagents were used: (a) $0.15 \mathrm{~N}-$ $\mathrm{NaOH} ;(b) 8 \mathrm{M}$-urea-I $\%(\mathrm{w} / \mathrm{v})$ mercaptoethanol, $\mathrm{pH} 8 \cdot 5 ;(c)$ the buffer system of Ellis (I96I) containing $0.05 \mathrm{M}-\mathrm{Na}_{2} \mathrm{CO}_{3}, 0.05 \mathrm{M}$-2-amino-2-methyl I,3-propane diol, $0.05 \mathrm{M}$-citric acid and $0.05 \mathrm{M}-\mathrm{NaH}_{2} \mathrm{PO}_{4}$, to which mercaptoethanol (50 mM) was added and the $\mathrm{pH}$ adjusted to 10.2 with $\mathrm{NaOH}$. These are referred to as alkali, urea-mercaptoethanol and reducing buffer, respectively.

Extractions were carried out by suspending spores or crystals in the above reagents for the times indicated. The clear crystal solution was used without further centrifugation. Spore suspensions were centrifuged $(3000 \mathrm{~g}, 15 \mathrm{~min})$ and re-extracted as indicated. In some experiments spores were extracted sequentially as follows: spores $(20 \mathrm{mg})$ were suspended for $\mathrm{I} h$ at room temperature in reducing buffer. After centrifugation $(3000 \mathrm{~g}$, I $5 \mathrm{~min})$, the extraction was repeated three times. The spores were washed once with $0.05 \mathrm{M}$-phosphate buffer $\mathrm{pH} 7{ }^{\circ}$, then disintegrated using a Braun disintegrator as described by Somerville (I97I). After centrifuging, the pellet was re-extracted four times by reducing buffer as described above. Each of the supernatants was retained.

Immunological experiments. Antiserum was prepared in rabbits immunized with solutions of crystals in reducing buffer, and a urea-mercaptoethanol extract of spores of B. cereus $\mathrm{T}$ (see Somerville, I 97I). All solutions were dialysed against 0.0 $5 \mathrm{M}-\mathrm{NaHCO}_{3}$ before injection.

Immunodouble diffusion in agar (Crowle, I96I) was as described by Delafield et al. (I968). Immunoprecipitation was carried out by incubating extracts with serum for $2 \mathrm{~h}$ at $37^{\circ} \mathrm{C}$, followed by 48 to $72 \mathrm{~h}$ at $4{ }^{\circ} \mathrm{C}$. Precipitates were collected by centrifuging at $4{ }^{\circ} \mathrm{C}(2500 \mathrm{~g}$, $20 \mathrm{~min}$ ). Where the protein in the precipitate was to be estimated, the precipitates were washed carefully by suspension and centrifugation (three times) in $0.9 \% \mathrm{NaCl}$ at $4{ }^{\circ} \mathrm{C}$.

Assay of toxicity. A feeding inhibition assay was used, modified from that described by Cooksey (I968). Leaf discs (4 cm diam) cut from fresh cabbage leaves were dipped in dilutions of the test material in $0.02 \%$ Triton X-100, placed on a clean surface, allowed to dry and placed in small $(5 \mathrm{~cm}$ diam) plastic Petri dishes to which 2nd or 3 rd instar larvae of Pieris brassicae (4 larvae/dish) or Plutella maculipennis (Io larvae/dish) were added. After incubation at $25^{\circ} \mathrm{C}$ until control leaf discs were totally consumed, the amount of leaf remaining was estimated photometrically by comparison with uneaten discs. To determine the toxicity values, duplicate assays were carried out on each of at least three dilutions of material, giving average values of between ro and $90 \%$ consumption.

The toxicity of material in the eluates from column chromatography was detected ty wetting leaves directly with samples from each fraction. 
Table I. Toxicity of crystals and extracts of spores

Bacillus cereus $64 \mathrm{a}$ spores (three $5 \mathrm{mg}$ portions) were extracted with the reagents indicated. Toxicity was determined on the supernatants after centrifuging and protein was estimated after dialysis. Other details are given in Methods.

\begin{tabular}{|c|c|c|c|}
\hline \multirow[b]{2}{*}{ Reagent } & \multicolumn{2}{|c|}{ B. cereus 64 a spores } & \multirow{2}{*}{$\begin{array}{l}\text { B. thuringiensis } \\
\text { S-9 crystals } \\
\text { (toxic units/ } \\
\text { mg protein) }\end{array}$} \\
\hline & $\begin{array}{l}\text { (mg protein extracted/ } \\
\text { IOO mg spores) }\end{array}$ & $\begin{array}{l}\text { (toxic units/ } \\
\text { mg spore) }\end{array}$ & \\
\hline Mercaptoethanol (pH I0.2) & $3 \cdot 8$ & 25 & 5000 \\
\hline $\mathrm{NaOH}(0.15 \mathrm{~N})$ & 15 & 0 & 580 \\
\hline $8 \mathrm{M}$-urea-mercaptoethanol & 12 & 0 & 900 \\
\hline
\end{tabular}

Estimation of protein. The method of Lowry, Rosebrough, Farr \& Randall (I95I) was used, with bovine plasma albumin as standard. All solutions in reducing buffer or ureamercaptoethanol were dialysed against at least one change of $0.015 \mathrm{M}-\mathrm{NaHCO}_{3}$ before assay.

Gel electrophoresis. Sodium dodecyl sulphate (SDS)-acrylamide gel electrophoresis was carried out using the procedure of Shapiro, Viñuela \& Maizel (1967) as adapted by Herbert, Gould \& Chain (197I) to include $4 \mathrm{M}$-urea in the sample and the gel. Gels were fixed with methanol, water and acetic acid (50:40: 10 , by vol.) for $16 \mathrm{~h}$, stained with Coomassie brilliant blue $(0.25 \%$ w/v) (Edward Gurr Ltd, London S.W. I4) and de-stained by repeated washing with $5 \%(\mathrm{w} / \mathrm{v})$ acetic acid. Densitometer scans of some gels were obtained using the gel scanning attachment, at $620 \mathrm{~nm}$, of a Gilford 240 spectrophotometer (Wright Scientific Ltd, Kenley, Surrey).

Amino acid analysis. Samples were hydrolysed for $\mathrm{I} 6 \mathrm{~h}$ with $6 \mathrm{~N}-\mathrm{HCl}$ at $\mathrm{I} 08^{\circ} \mathrm{C}$. Amino acids in the hydrolysate were estimated using a Technicon NC-I autoanalyser (long column) run with a discontinuous gradient from $\mathrm{pH} 2 \cdot 75$ to $5 \cdot 0$.

Chemicals. Analar grade components of media buffers, etc., were obtained from BDH; specialized media components were from Oxoid; bovine plasma albumin was from Armour Pharmaceutical Co. Ltd, Eastbourne, Sussex; 2-mercaptoethanol was from Sigma; and Triton X-10o and papain $(2 \times$ crystallized $)$ were from BDH. Urea solutions were de-ionized by slow filtration through Amberlite MB-3 mixed resin (BDH). Trypsin and chymotrypsin were obtained from Boehringer Corp. (London) Ltd.

Radioactivity was estimated by counting in an Intertechnique SL30 scintillation counter using a scintillation mixture of $85 \mathrm{~g}$ naphthalene and $8 \mathrm{~g}$ butyl PBD [2-(4-t-butyl phenyl)5(4-biphenylyl)-I,3,4 oxadiazole] (Intertechnique Ltd, Portslade, Sussex) in I 1 dioxane which was purified by passing over activated alumina.

RESULTS

Toxicity in spores of $B$. cereus and $B$. thuringiensis

In preliminary experiments, urea-mercaptoethanol and alkali extracts of $B$. cereus 64 a or $B$. cereus $\mathrm{T}$ spores were found to be non-toxic. When purified spores of these organisms were extracted with reducing buffer at $\mathrm{pH} 10 \cdot 2$ some toxic activity was found in the supernatant. The activity for $B$. cereus $64 \mathrm{a}$ was about 30 toxic/units $\mathrm{mg}$ extracted protein. When crystals of $B$. thuringiensis were dissolved in the three reagents and dialysed before testing for toxicity, the preparations dissolved in urea-mercaptoethanol and alkali were considerably less toxic than those dissolved in reducing agent at $\mathrm{pH}$ 10.2. SDS-gel electrophoresis of the solutions and extracts obtained with these reagents indicated that with crystals the pattern 


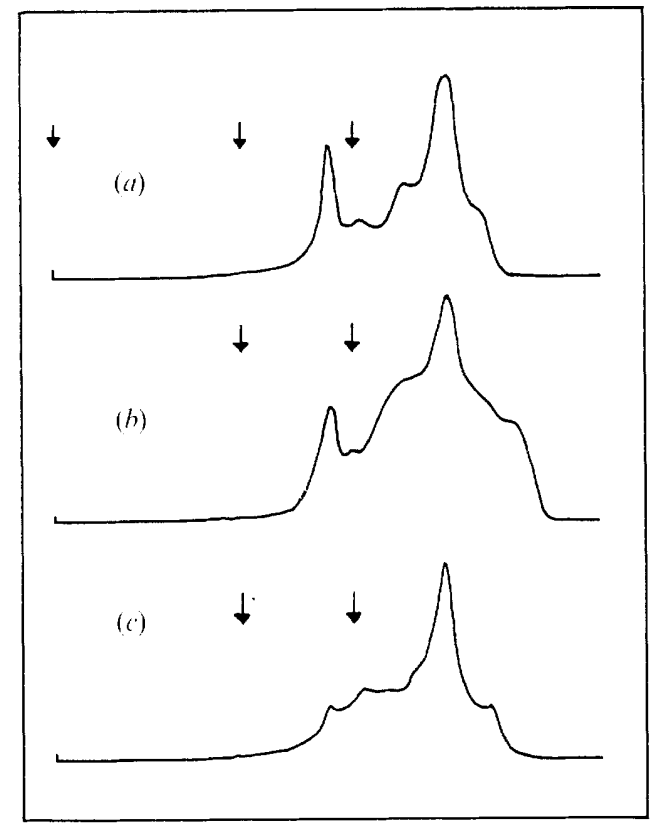

Fig. I. Densitometer scans of SDS-acrylamide gels of spore extracts. Extracts of $B$. cereus 64 a spores were prepared as described in Table I. After overnight dialysis against $0.15 \mathrm{M}-\mathrm{NaHCO}_{3}$, samples were examined by acrylamide gel electrophoresis: (a) $0.15 \mathrm{~N}-\mathrm{NaOH}$ extract, I $25 \mu \mathrm{g}$ protein; $(b)$ urea-mercaptoethanol extract, I Io $\mu \mathrm{g}$ protein; (c) reducing buffer extract, I30 $\mu \mathrm{g}$ protein. The arrows indicate the top of the gel and mobilities of BSA monomer and dimer. Other details are given in Methods.

obtained was similar with each reagent, although the bands in alkali extracts were consistently less well defined.

With spores there was a difference in both the amount of material extracted (Table I) and the electrophoresis profile (Fig. I). Less protein was extracted by the reducing buffer than by the other two methods and there was a prominent band of molecular weight about 32000 in all three extracts. A similar band was also apparent in extracts of spores of other species subjected to electrophoresis on SDS gels (Fig. 2). The extracts obtained from crystals and spores by these three reagents also reacted differently with crystal antiserum in Ouchterlony double diffusion tests. Toxic material could also be extracted from spores of $B$. thuringiensis and activity was much higher than with $B$. cereus $64 a$. The SDS-gel electrophoresis pattern of extracts of $B$. thuringiensis was different from that obtained from other spore-formers; faint bands were visible running in the same position as some of the major crystal bands. Extracts of spores from B. cereus $\mathrm{T}, B$. megaterium NCIB8508 and the two $\mathrm{cr}$ mutants of $B$. thuringiensis were all slightly toxic, with about the same activity as that of an extract from spores of $B$. cereus 64 a.

The toxicity in each case was heat-labile, all activity being lost after heating for to min at $100{ }^{\circ} \mathrm{C}$.

Toxicity in whole spores. Whole spores of B. thuringiensis were toxic to both Pieris brassicae and Trichoplusia $n i$ when used in the same bioassay system (Fig. 3). The toxicity of spores was less than in crystals and solutions of crystals were about as toxic as undissolved crystals.

Toxicity in proteolytic digests of spores. Spores were incubated with several proteolytic enzymes as well as gut juice from P. brassicae. After centrifuging, the pellets were extracted 


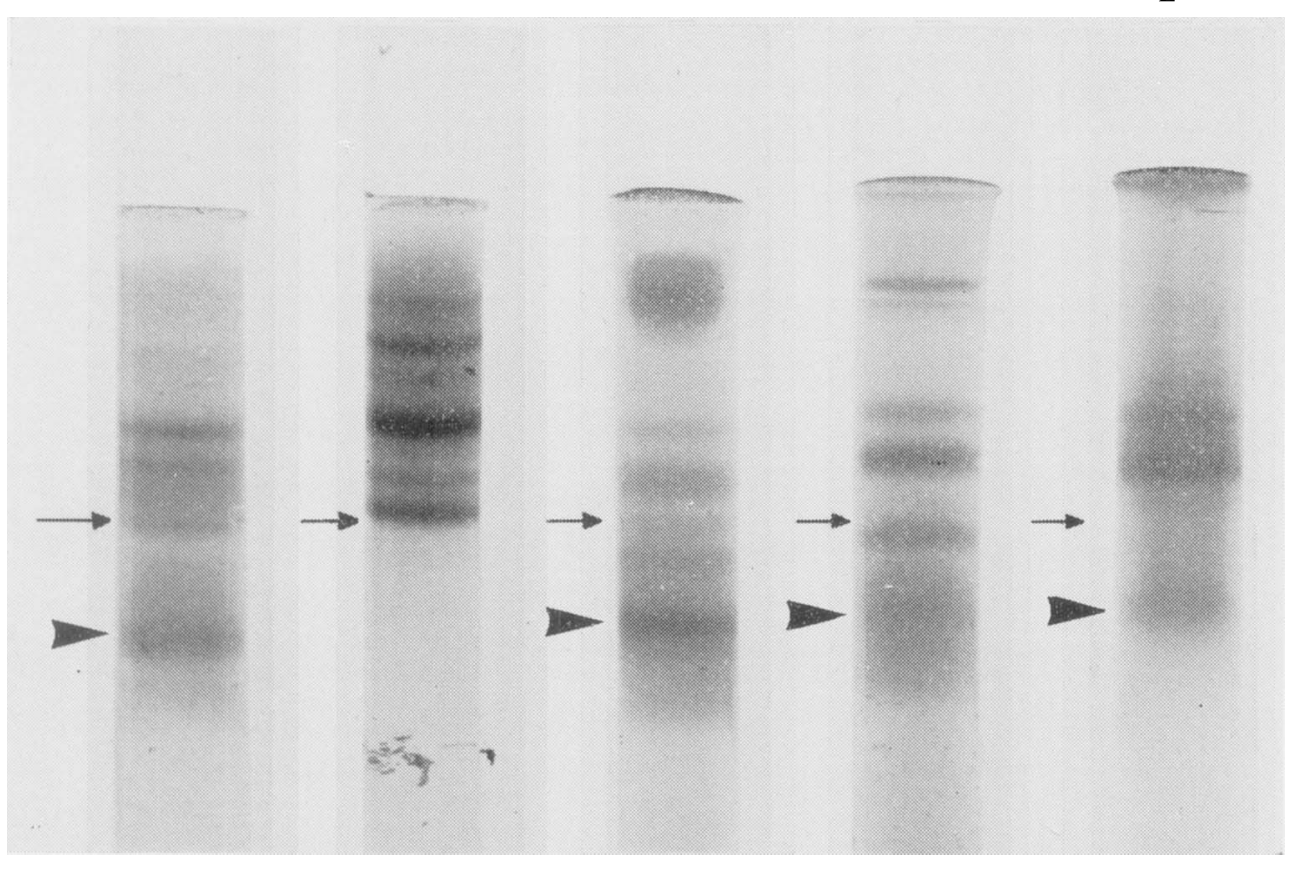

Fig. 2. SDS-acrylamide gels of crystal solution and spore extracts. Spores were extracted with reducing buffer for $\mathrm{I} \mathrm{h}$ at $30^{\circ} \mathrm{C}$. After centrifuging they were re-extracted with $\mathrm{I} \mathrm{ml}$ of the same buffer and the supernatants pooled. Crystals were dissolved directly in reducing buffer. (A) $B$. thuringiensis S-9 spore extract, $45 \mu \mathrm{g}$; (B) crystal solution, IOO $\mu \mathrm{g}$; (C) B. thuringiensis $\mathrm{S}-9$ HB2 spore extract, $50 \mu \mathrm{g}$; (D) B. cereus $\mathrm{T}$ spore extract, $50 \mu \mathrm{g}$; (E) B. megaterium 8508 spore extract, $50 \mu \mathrm{g}$. The narrow arrows indicate the mobility of BSA monomer, the broad arrows indicate the band described in the text.

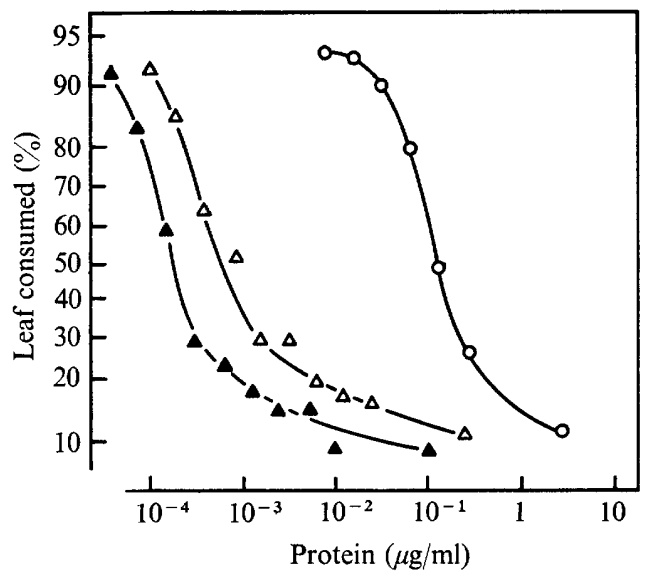

Fig. 3. Toxicity of spores and extracts of spores of $B$. thuringiensis to Pieris brassicae. Extracts of spores and solutions of crystals were prepared by suspension in reducing buffer; the spores were centrifuged and the precipitate discarded. Dilutions of the two clear solutions were prepared as described in Methods. Whole spores were suspended directly in the phosphate-Triton solution. Protein was estimated from the dry weight of crystals, as $50 \%$ of the dry weight of whole spores and as $5 \%$ dry weight extracted from spores by reducing buffer. $\boldsymbol{\Delta}$, Crystal solution; $\triangle$, spore extract; $\bigcirc$, whole spores. 


\section{Table 2. Toxicity of proteolytic digests of spores}

Bacillus thuringiensis serotype 9 spores were suspended $(10 \mathrm{mg} / \mathrm{ml})$ in $0.0 \mathrm{I} \mathrm{M}-\mathrm{NaHCO}$. Portions $\left(\mathrm{I} \circ \mathrm{\textrm {ml }}\right.$ ) were incubated at constant $\mathrm{pH} 10$ and $30^{\circ} \mathrm{C}$ with $\mathrm{I} \mathrm{mg}$ of the enzymes indicated. After $2 \mathrm{~h}$ the suspensions were centrifuged $(35000 \mathrm{~g} ; 30 \mathrm{~min})$. The supernatants were stored at $0^{\circ} \mathrm{C}$ and the pellet was extracted with reducing buffer (see Methods) for I $\mathrm{h}$ at room temperature. The supernatants were assayed for toxicity to Pieris brassicae as described in Methods.

\begin{tabular}{|c|c|c|c|c|}
\hline \multirow[b]{2}{*}{ Treatment } & \multicolumn{2}{|c|}{ Toxicity in supernatant } & \multicolumn{2}{|c|}{ Toxicity in extract of pellets } \\
\hline & $\begin{array}{l}\text { Dilution for } \\
50 \% \text { inhibition }\end{array}$ & $\begin{array}{c}\text { Toxic units/ } \\
\text { mg spores }\end{array}$ & $\begin{array}{l}\text { Dilution for } \\
50 \% \text { inhibition }\end{array}$ & $\begin{array}{c}\text { Toxic units/ } \\
\text { mg spores }\end{array}$ \\
\hline None & Not toxic & - & I $: 430$ & $43 \cdot 2$ \\
\hline Trypsin & $I: 90$ & $9 \cdot 9$ & I $: 100$ & 10.0 \\
\hline Chymotrypsin & $\mathrm{I}: 80$ & $8 \cdot 0$ & I : I IO & $10 \cdot 4$ \\
\hline Papain & $\mathrm{I}: 33$ & $3 \cdot 0$ & $1: 130$ & $12 \cdot 8$ \\
\hline
\end{tabular}

Table 3. Serum inactivation of toxin from spores of Bacillus cereus

Bacillus cereus $64 \mathrm{a}$ spores $(300 \mathrm{mg})$ were extracted for $\mathrm{I}$ h with reducing buffer $(5 \mathrm{ml})$. After washing with reducing buffer, I $\mathrm{ml}$ portions of the combined supernatants $(800 \mu \mathrm{g}$ protein $/ \mathrm{ml})$ were incubated with $\mathrm{I} \mathrm{ml}$ of the sera indicated and toxicities were determined on $\mathrm{I} \mathrm{ml}$ of the supernatant. Other details are given in Methods.

\begin{tabular}{lcc}
\multicolumn{1}{c}{ Serum } & $\mathrm{LC}_{50}$ & $\begin{array}{c}\text { Toxic units/mg } \\
\text { protein in spore extract }\end{array}$ \\
Pre-bled & $\mathrm{I}: 60$ & $\mathrm{I} 50$ \\
B. cereus T coat & $\mathrm{I}: 48$ & $\mathrm{I} 20$ \\
Saline & $\mathrm{I}: 60$ & $\mathrm{I} 50$ \\
B. thuringiensis crystal & (Negative) & 0 \\
None & $\mathrm{I}: 64$ & $\mathrm{I} 60$
\end{tabular}

with reducing buffer at $\mathrm{pH}$ I0.2 and the toxicity was estimated in each supernatant (Table 2 ). The sum of activities in each proteolytic digest and the subsequent extract was approximately equal to the activity from whole spores (Table 2).

\section{Antibody inactivation of toxin}

Extracts of spores of B. cereus 64 a were incubated with various serum preparations (Table 3). After removal of the precipitates by centrifugation the supernatants were examined for toxicity. Crystal antiserum completely inactivated the toxin, whereas pre-bled serum or antiserum to a spore coat preparation from B. cereus $\mathrm{T}$ had virtually no effect. No activity could be recovered in the pellets from those incubations in which precipitates were formed, even after dissociation with $8 \mathrm{M}$-urea. Precipitation with either anti-crystal serum or anti-B. cereus $\mathrm{T}$ 'coat' serum decreased the ability of the serum to react with homologous crystal or spore extract, respectively, in Ouchterlony tests but apparently did not affect the ability to react with heterologous extract. Similar results were obtained with spores of $B$. thuringiensis S-9. In one experiment the amount of protein precipitated was estimated using a radioactive spore preparation. Each serum precipitated approximately half the radioactivity in the extract.

Incubation of the toxic extract from $B$. cereus 64 a with anti-crystal serum resulted in precipitate formation (Fig. 4) although precipitation was much less than with an equivalent amount of crystal material. No precipitate was formed with pre-bled serum or by a soluble extract of spores.

The toxic fraction from $B$. thuringiensis also cross-reacted with a partially purified prepara- 


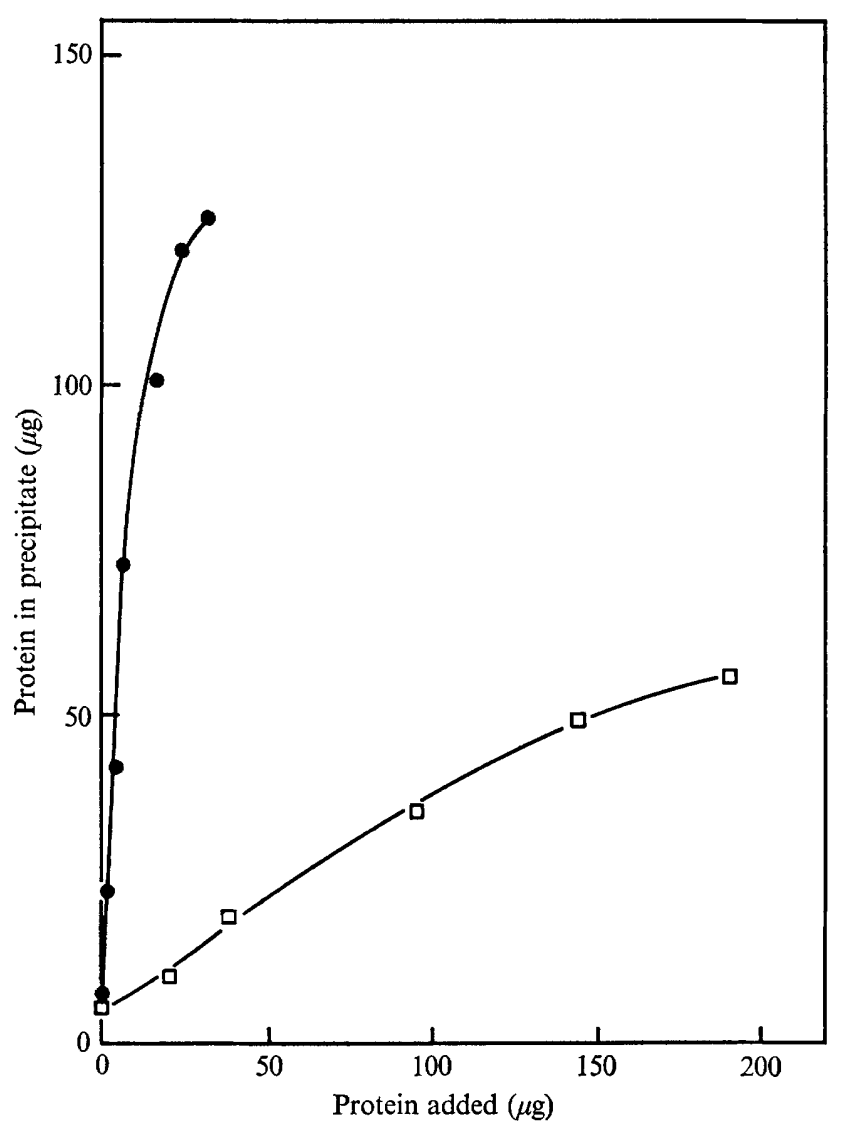

Fig. 4. Precipitation of the toxic fraction from B. cereus 64 a by antiserum to crystals of $B$. thuringiensis. A series of tubes was set up containing the following (in $250 \mu \mathrm{l}$ ): antiserum, I00 $\mu \mathrm{l}$; $0^{\circ}$ I M$\mathrm{NaCl}, 50 \mu \mathrm{l}$; sample, dialysed against $0.0 \mathrm{I} \mathrm{M}-\mathrm{NaHCO}_{3}, 100 \mu \mathrm{l}$ containing the amount of protein indicated. After $2 \mathrm{~h}$ at $37{ }^{\circ} \mathrm{C}$ the tubes were stored at $4{ }^{\circ} \mathrm{C}$ for $72 \mathrm{~h}$ then centrifuged. The precipitate was washed twice with $0.85 \% \mathrm{NaCl}$ and the protein in the washed precipitates estimated by the method of Lowry et al. (I95I) using I $\mathrm{ml}$ total volume. C, Crystal extract; $\square, B$. cereus 64a spore extract, concentrated material excluded from Sephadex G-200.

tion of crystal toxin. This toxic fraction was obtained by gel chromatography of a partially hydrolysed crystal preparation, and contained one major polypeptide detected on SDS-gel chromatography with a molecular weight similar to that of the toxin described by Herbert et al. (197I).

\section{Chromatography on Sephadex}

Initial experiments with dialysed preparations indicated that components in reducing buffer extracts of spores were excluded from Sephadex G-200. In an attempt to dissociate this material, columns were prepared in reducing buffer and material dissolved in reducing buffer was eluted with the reducing buffer itself. Although this altered the exclusion properties of the gel and it was impossible to locate eluted protein by extinction at $280 \mathrm{~nm}$, protein was detected by reaction in Ouchterlony plates with crystal antiserum. One major peak, coinciding with the void volume, was found from spores of both $B$. cereus 64 a and $B$. thuringiensis. Later, the concentration of mercaptoethanol in the eluting buffer was 


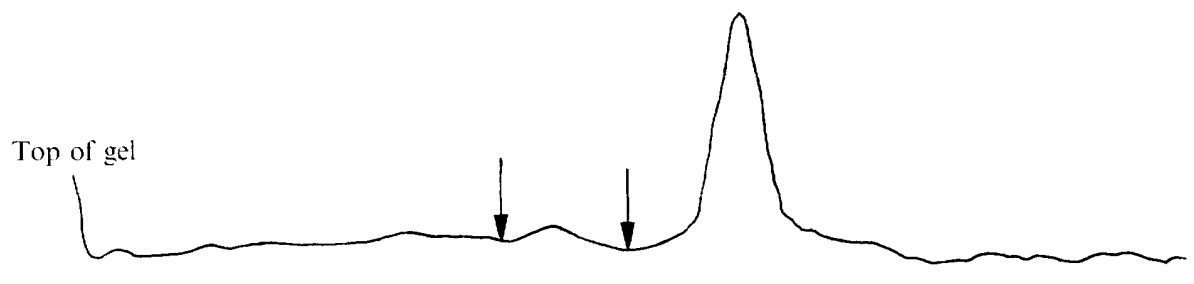

Fig. 5. Densitometer tracing of partially purified toxin. Fractions from the major peak excluded from Sephadex G-200 were pooled and concentrated by ultrafiltration. After dialysis against 0.015 $\mathrm{M}-\mathrm{NaHCO}{ }_{3}$ a sample was subjected to SDS-gel electrophoresis (see Methods). The arrows indicate the approximate position of BSA monomer (mol. wt 67000) and dimer.

Table 4. Amino acid analysis of toxin from spores of $B$. cereus

Results (average of two determinations) are expressed as $\mu \mathrm{mol} / \mathrm{ro0} \mu \mathrm{mol}$ amino acids recovered.

Spore toxin Crystals B. thuringiensis $\mathrm{S}-3^{*}$

Aspartic acid
Threonine
Serine
Glutamic acid
Proline
Glycine
Alanine
Valine
Cystine
Methionine
Isoleucine
Leucine
Tyrosine
Phenylalanine
Lysine
Histidine
Arginine

$\begin{array}{rr}\text { I3.I } & \text { I } 2 \cdot I \\ 6 \cdot 7 & 6 \cdot I \\ 6 \cdot 2 & 7 \cdot I \\ 10 \cdot 4 & I I \cdot 7 \\ 5 \cdot 3 & 4 \cdot 7 \\ I 0 \cdot I & 7 \cdot 5 \\ 8 \cdot 4 & 5 \cdot 4 \\ 7 \cdot 9 & 7 \cdot 9 \\ 0 \cdot 9 & 1 \cdot 5 \\ 1 \cdot 0 & 0 \cdot 9 \\ 4 \cdot 7 & 5 \cdot 9 \\ 8 \cdot 6 & 8 \cdot I \\ 2 \cdot 0 & 4 \cdot 7 \\ 4 \cdot 9 & 5 \cdot I \\ 6 \cdot 7 & 3 \cdot I \\ I \cdot 6 & 2 \cdot I \\ 2 \cdot I & 6 \cdot 2\end{array}$

* Taken from Somerville et al. (1968).

decreased to $5 \mathrm{~mm}$. This allowed the protein to be detected by u.v. absorption. The peak fractions were collected and concentrated by ultrafiltration and SDS electrophoresis revealed a single major component of mol. wt 32000 (Fig. 5). This material had a ratio of $E_{280}: E_{260}$ of I : I. Toxicity in the eluate from chromatograms was located qualitatively by dipping leaves in each fraction. The toxicity coincided with the void volume and in the concentrated void material toxicity was about the same as in the original extract.

\section{Amino acid analysis}

The concentrated fraction from Sephadex G-200 chromatography of the $B$. cereus $64 a$ extract was hydrolysed and the amino acid content determined (Table 4). The total recovery of amino acids was roughly equivalent to the protein estimated colorimetrically in the sample after dialysis. The analysis is similar, but not identical, to that of the whole crystal from B. thuringiensis. 
Table 5. Extraction of toxin from spores of B. thuringiensis

Bacillus thuringiensis S-9 spores ( $20 \mathrm{mg}$ ) were sequentially extracted with the reagents shown. Incubations with reducing buffer were for $\mathrm{i} h$ at room temperature.

\begin{tabular}{|c|c|c|c|}
\hline Reagent & $\begin{array}{c}\text { Protein } \\
\text { extracted }(\mathrm{mg})\end{array}$ & $\mathrm{LC}_{50}$ & $\begin{array}{c}\text { Toxic units/ } \\
\text { mg protein extractec }\end{array}$ \\
\hline \multicolumn{4}{|l|}{ Reducing buffer extract } \\
\hline I & 0.48 & $I: 1600$ & 8000 \\
\hline 2 & 0.20 & I : 160 & 800 \\
\hline 3 & O.II & I $: 35$ & 310 \\
\hline 4 & 0.05 & $\mathrm{I}: \mathrm{I}$ & 35 \\
\hline Phosphate buffer (0.05 M) & - & NT & o \\
\hline Supernatant from breaking & $I \cdot O$ & I $: 20$ & 27 \\
\hline Water wash after breaking & 0.5 & ST & 5 \\
\hline \multicolumn{4}{|l|}{$\begin{array}{l}\text { Reducing buffer extract, } \\
\text { after breaking }\end{array}$} \\
\hline I & 0.30 & $\mathrm{I}: \mathrm{I}$ & 6 \\
\hline 2 & 0.12 & $I: I$ & 15 \\
\hline 3 & 0.12 & $I: I$ & I 5 \\
\hline
\end{tabular}

Extraction of toxin from spores

Spores of $B$. cereus $64 \mathrm{a}$ and $B$. thuringiensis were extracted four times with reducing buffer and then washed with phosphate buffer. After disintegration and centrifugation, the broken spores were extracted again with reducing buffer. The toxicity and protein in each extract were estimated (Table 5 ). Most of the toxicity ( $>80 \%$ ) was extracted in the first extraction and the toxic activity/mg extracted protein fell markedly over the extraction period, suggesting that the toxin was being preferentially extracted at the start. Little or no toxic activity was found in the 'soluble' fraction of spores, even where initial extraction with reducing buffer was omitted. Likewise, little activity was found in the protein extracted with reducing buffer from extracted, broken spores. Treatment in the Braun disintegrator did not affect crystal toxicity.

\section{DISCUSSION}

Considerable evidence has accumulated (see above, and Lecadet \& Dedonder, 1971; Ribier, 1971; Lecadet, Chevrier \& Dedonder, 1972; Ribier \& Lecadet, I973; Herbert \& Gould, 1973) indicating a relationship between the protein of the crystal of $B$. thuringiensis and spore material which is solubilized under conditions similar to those necessary to dissolve crystals. However, the toxicity of spore extracts has not previously been reported although whole spores are known to be toxic. Earlier attempts to demonstrate toxicity in solubilized materials have evidently failed because of the reagent used to solubilize the spore material. The present work indicates that both urea-mercaptoethanol and alkali inactivate the crystal toxin to some extent. Although SDS-gel electrophoresis suggests that the material extracted from spores by these reagents is not toxic, it contains the particular components extracted at $\mathrm{pH}$ io.

The material extracted from spores of $B$. cereus $64 \mathrm{a}$ is far less active than that from spores of $B$. thuringiensis. There are several possible explanations for this. For example, (I) the spores of $B$. thuringiensis could be contaminated with crystals, or (2) contain more active material, or (3) the material extracted from spores of $B$. thuringiensis could be intrinsically more active. All spore preparations contained less than $0.1 \%$ crystals by microscopic 


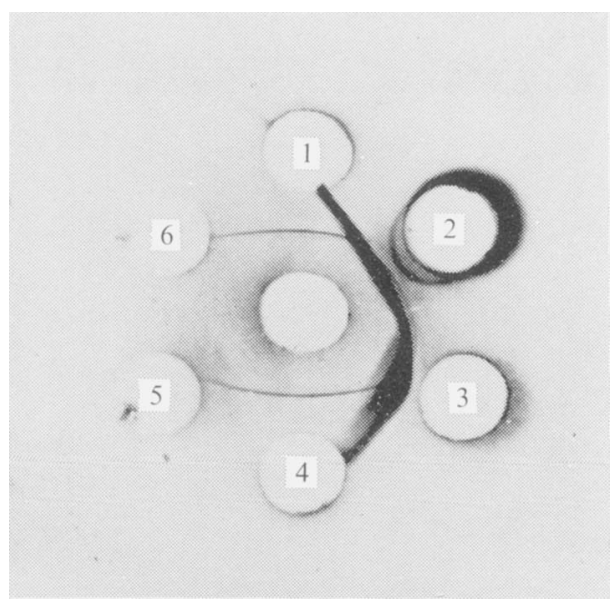

Fig. 6. Immunological cross-reaction of an alkali extract of Clostridium sporogenes with a crystal solution. Centre well, antiserum to S-9 crystals: wells I and $4,50 \mu \mathrm{l} \mathrm{C}$. sporogenes extract (50 $\mu \mathrm{g}$ protein); wells 2,3 and 5 , S-9 crystal solution $(65,32$ and $\mathrm{I} \cdot 5 \mu \mathrm{g}$, respectively); well 6 , 0.0 5 M$\mathrm{NaHCO}_{3}$.

examination. As the dry weight of crystals is about one-third of that of spores, this means that $0.03 \%$ of the spore dry weight could be free crystals and a maximum of $\mathrm{I} \%$ of the spore extract could be dissolved crystals. However, as the spore extract is about a third to a half as toxic as the crystal solution it seems unlikely that contamination is a major source of toxicity in spores. The second possibility seems unlikely on its own to account for the difference in activity as there was no marked variation in any single common component on SDS-gel electrophoresis of spore extracts from different species. The bulk of the material extracted was always protein, as estimated by u.v. absorption and the Lowry method. It therefore seems likely that the material in $B$. thuringiensis spores is intrinsically more toxic, although confirmation of this will await purification of the $B$. thuringiensis spore toxin and identification of its mode of action.

The toxin is extracted from spores under conditions remarkably similar to those used by Raybin, Bertsch \& Kornberg (1972) to extract phospholipase activity from spores of a $B$. cereus strain. Further, the $B$. cereus 64 a activity has a major component of mol. wt 32000 , and Raybin et al. (1972) reported a mol. wt of 32000 for the phospholipase. Although this suggests that the toxin may act as a phospholipase we have not been able to demonstrate phospholipase activity in crystal or spore extracts. The molecular weight of the $B$. cereus 64a toxin is apparently about half that of the fastest running component of the crystal as revealed by SDS-gel electrophoresis. It is possible that the $B$. cereus 64 a preparations contain a small amount of an active component which we have not detected. In any event, the spore and crystal toxins share common antigens as spore toxicity is inactivated by crystal antiserum. The strong cross-reaction observed in Ouchterlony double diffusion plates (e.g. Fig. 6) suggests that a major component of the spore extract is involved. This serum is specific to crystal components and specific spore components (Short, Walker, Thomson \& Somerville, 1974), and it can be concluded that the spore toxins are located in those parts of the spore which react with crystal antiserum, namely the exosporium and spore-coat. Preliminary results confirming the location of toxicity in the exosporium of $B$. thuringiensis have recently been reported (Scherrer, Pillinger \& Somerville, 1974).

The present experiments indicate that toxic material is located in the outer layers of the 
spore and that it can be released by incubation with proteolytic enzymes and gut juice from susceptible insect larvae. The results suggest that the spore may contribute to the efficiency of commercial insecticidal preparations of Bacillus thuringiensis.

The authors thank W. H. Kingham for the preparation of antisera, N. Crabtree for the amino acid analyses, G. W. Gould for the extract of Clostridium sporogenes spores, and J. N. Claus who identified the culture.

\section{REFERENCES}

CooKsEy, K. E. (1968). Purification of a protein from Bacillus thuringiensis toxic to larvae of Lepidoptera. Biochemical Journal ro6, 445-454.

Crowle, A. J. (1961). Immunodiffusion. New York: Academic Press.

Delafield, F. P., Somerville, H. J. \& RitTenberg, S. C. (1968). Immunological homology between crystal and spore protein of Bacillus thuringiensis. Journal of Bacteriology 96, 71 3-720.

EcLis, D. A. (I96I). A new universal buffer. Nature, London 19I, 1099.

Herbert, B. N. \& Gould, H. J. (1973). Biosynthesis of the crystal protein of Bacillus thuringiensis var. tolworthi. I. Kinetics of formation of the polypeptide components of the crystal protein in vivo. European Journal of Biochemistry 37, 44I-448.

Herbert, B. N., Gould, H. J. \& ChaIN, E. B. (I97I). Crystal protein of Bacillus thuringiensis var. tolworthi. Subunit structure and toxicity to Pieris brassicae. European Journal of Biochemistry 24, 366-375.

Lecadet, M. M., Chevrier, G. \& Dedonder, R. (1972). Analysis of a protein fraction in the spore coats of Bacillus thuringiensis. European Journal of Biochemistry 25, 349-358.

LeCADET, M. M. \& DEDONDER, R. (197I). Biogenesis of the crystalline inclusion of Bacillus thuringiensis during sporulation. European Journal of Biochemistry 23, 282-294.

Lowry, O. H., Rosebrough, N. J., Farr, A. L. \& Randall, R. J. (I95I). Protein measurement with the Folin phenol reagent. Journal of Biological Chemistry I93, 265-275.

RAYBin, D. M., BertsCh, L. L. \& Kornberg, A. (1972). A phospholipase in Bacillus megaterium unique to spores and sporangia. Biochemistry II, I754-I 760 .

RIBIER, J. (I97I). L'inclusion parasporale du Bacillus thuringiensis var. Berliner I7I5: moment et site de son initiation, rapports avec l'ADN sporangial. Comptes rendus hebdomadaire des séances de l'Académie des sciences 273 , I444-I 447.

RibieR, J. \& LECADET, M. M. (I973). Étude ultrastructurale et kinetique de la sporulation de Bacillus thuringiensis, 1715. Remarques sur la formation de l'inclusion parasporale. Annales de Microbiologie (Institut Pasteur) I24A, 3 I I-344.

Scherrer, P., Pillinger, R. N. \& Somerville, H. J. (I974). Toxicity to Lepidoptera in the exosporium membrane of spores of Bacillus thuringiensis. Proceedings of the Society for General Microbiology I, 45.

Shapiro, A. L., Viñuela, E. \& Maizel, J. V., Jun. (1967). Molecular weight estimation of polypeptide chains by electrophoresis in SDS-polyacrylamide gels. Biochemical and Biophysical Research Communications 28, 81 5-820.

Short, J., Walker, P., Thomson, R. O. \& Somerville, H. J. (1974). The fine structure of Bacillus finitimus and Bacillus thuringiensis spores with special reference to the location of crystal antigen. Journal of General Microbiology 84, 261-276.

SOMERVILLE, H. J. (1971). Formation of the parasporal inclusion of Bacillus thuringiensis. European Journal of Biochemistry 18, 226-237.

Somerville, H. J., Delafield, F. P. \& Rittenberg, S. C. (1968). Biochemical homology between crystal and spore protein of Bacillus thuringiensis. Journal of Bacteriology 96, 721-726.

Somerville, H. J., Delafield, F. P. \& Rittenberg, S. C. (1970). Urea-mercaptoethanol-soluble protein from spores of Bacillus thuringiensis and other species. Journal of Bacteriology 1or, 55 I-560. 